\title{
Tables of legislation
}

\section{TABLE OF AGREEMENTS, CONVENTIONS AND TREATIES}

Abidjan Convention for Cooperation in the Protection and Development of the Marine and Coastal Environment of the West and Central African Region 1981 438

African Charter of Human and Peoples' Rights 1981 394,396

Protocol 396

African Charter on the Rights and Welfare of the Child 1990 104, 397, 482

African Union Convention on Cyber Security and Personal Data Protection 2014 ... 408

African Union Convention on the Assistance and Protection of Internally Displaced Persons in Africa 2009 (Kampala Convention) 363, 365, 367-9, 371,

Agreement among the Governments of the Participating States of the Black Sea Economic Cooperation on collaboration in Emergency Assistance and Emergency Response to Natural and Man-made Disasters 1998

Agreement between Argentina and Chile on Cooperation in Case of Catastrophes 1997 345

Agreement between Austria and Albania on Mutual Assistance on the Case of Disasters or Serious Accidents 2010 345

Agreement between Caribbean Member States on Regional Cooperation on Natural Disasters 1999 458

Agreement between Finland and Burkina Faso Regarding Support to the Management of Bush Fires 1998 346

Agreement between Finland and Russian Federation on Cooperation to Avert Disasters and Prevent their Consequences 1994 345
Agreement between France and Croatia on Assistance and Cooperation in the area of Civil Protection and Security 2009 346

Agreement between Germany and Hungary on Mutual Assistance in the Event of Disasters or Serious Accidents 1997 346

Agreement between Latvia and Azerbaijan on Cooperation in the Prevention and Mitigation of Emergency Situations 2011 346

Agreement between Latvia and Russian Federation on Mutual Cooperation 1992 345,347

Agreement between Lithuania and Poland Concerning their Common State Frontier and Cooperation and Mutual Assistance in Frontier Matters 1998 $345,347-8$

Agreement between Spain and France on Emergency Situations, Civil Protection and Security 2009 345,348

Agreement between Spain and Portugal

Regarding Technical Cooperation and Mutual Assistance and Civil Protection 1993

Agreement between the United States and Belarus Regarding Cooperation to Facilitate the Provision of Assistance 1996

Agreement between the United States and Canada Regarding Wildfires 1982 ... 345,

Agreement Concerning the United States Relief Assistance to the Chinese People with Exchange of Notes 1947 231

Agreement Establishing the Caribbean Disaster Emergency Management Agency (CDEMA) 2008 ........... 231, 442

Agreement for the Implementation of UNCLOS Provisions Relating to the Conservation and Management of Straddling Fish Stocks and Highly Migratory Fish Stocks 1995 182 
Agreement on Cooperation between Spain and Argentina on Cooperation on Disaster Preparedness and Prevention, and Mutual Assistance in the Event of Disasters 1988 231,441

Agreement on Economic Cooperation between New Zealand and the Separate Customs Territory of Taiwan, Penghu, Kinmen, and Matsu 2013 211

Agreement on Sanitary and Phytosanitary Measures (1995, WTO) 34

Agreement on the Establishment of the Civil-Military Emergency Planning Council for Southeastern Europe 2001 $441-2$

Agreement on the Privileges and Immunities of the International Atomic Energy Agency (IAEA) 1959 232

Alma-Ata Declaration on Primary Health Care 1978 473

American Convention on Human Rights 1969 95,394

Arab Convention on Regulating Status of Refugees in the Arab Countries 1994 378

ASEAN Agreement on Disaster Management and Emergency Response 2005 ... 443-4, 458,468

art. 3 $195,257,469,476$

art. 4 195,476

art. 14 232

ASEAN Agreement on Transboundary Haze Pollution (2003) 343

ASEAN Declaration on Mutual Assistance on Natural Disasters 1976 458

Australia-Malaysia Free Trade Agreement 2012 211-12

Bonn Agreement for Cooperation in Dealing with Pollution of the North Sea by Oil and Other Harmful Substances 1983 438

Bruges Resolution on Humanitarian Assistance 2003

art. I 475

art. III 476

art. V 462

art. VI 462

art. VII 453

Canada-United States Reciprocal Forest Fire Fighting Arrangement; Operating Plan For 2015 346

Cartagena Declaration on Refugees 1984

311,378
Cartagena Protocol on Biosafety 2000 ..... 158,

Convention against Torture and Other Cruel, Inhuman or Degrading Treatment or Punishment 1984

Convention against Transnational Organized Crime 2000 127,396

Protocol against Smuggling of Migrants 2001

Convention and Statute Establishing an International Relief Union (IRU) 1927 $49-51$

Convention between Denmark and Germany on Mutual Assistance in the Event of Disasters or Serious Accident 1985 231,441

Convention concerning the Prevention of Major Industrial Accidents 1993 ...... 194,

Convention for Cooperation in the Protection and Development of the Marine and Coastal Environment of the West and Central African Region 1981 438

Convention for the Protection and Development of the Marine Environment of the Wider Caribbean Region 1983

Convention Governing the Specific Aspects of Refugee Problems in Africa 1969 (OAU) 311,364

Convention on Assistance in the Case of Nuclear Accident or Radiological Emergency 1986 167, 231, 468-9

Convention on Biological Diversity 1992 $157-8,182,267-8$

Convention on Cybercrime 2001 408

Convention on Early Notification of a Nuclear Accident 1986 167

Convention on International Information Security (Draft, September 2011) ..... 409

Convention on Long-Range Transboundary Air Pollution 1979 $342-3$

Convention on Nuclear Safety 1994 . 167, 439

Convention on Persistent Organic Pollutants 2001 (Stockholm Convention) 182

Convention on Protection of Children and Cooperation in Respect of Inter-country Adoption 1993 397

Convention on the Ban of the Import into Africa and the Control of Transboundary Movement and Management of Hazardous Wastes within Africa 1991 (Barnako Convention) 126 
Convention on the Consent to Marriage, Minimum Age for Marriage and Registration of Marriages 1962 396

Convention on the Control of Transboundary Movements of Hazardous Wastes and Their Disposal 1989 (Basel Convention) 126

Convention on the Elimination of All Forms of Discrimination against Women 1979 200, 331, 395-6

Convention on the Elimination of All Forms of Racial Discrimination 1965 ......... 200, 402,505

Convention on the Law of the Sea 1982 (UNCLOS) $162-3$

Convention on the Non-Navigational Uses of International Watercourses 1997 (UN Watercourses Convention) .... 165, 307-9, art. 4 317,319 art. 5 308 art. 6 308

art. 7 308

art. 10 308

art. 27 165,309

art. 28

art. 29

art. 32 309 316

Convention on the Political Rights of Women 1953 395

Convention on the Prior Informed Consent Procedure for Certain Hazardous Chemicals and Pesticides in International Trade 1998 (Rotterdam Convention) 182

Convention on the Privileges and Immunities of the Specialized Agencies 1947 ..... 232

Convention on the Privileges and Immunities of the United Nations 1946 232,521

Convention on the Prohibition of Military or Any Other Hostile Use of Environmental Modification Techniques 1977 127

Convention on the Protection and Use of Transboundary Watercourses and International Lakes 1992 (UNECE) $165-6,319$

Convention on the Protection of the Rhine 1999 166

Convention on the Rights of Persons with Disabilities 2006 ...... 104, 199, 385, 391, 399-400, 482

art. 4 401

art. 5 400 art. 11 385-6, 400-401

art. 12 400

art. 28 331

Convention on the Rights of the Child 1989 18, 24, 104, 200, 385, 391, 396-7, 483-4, 498

art. 2 ……………............................ 483

art. 3 ................................................. 397-8

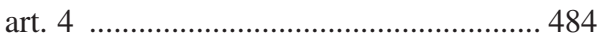

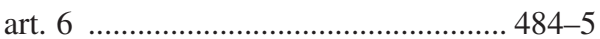

art. 7 ........................................... 398, 485

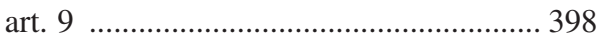

art. 11 ..................................................... 484

art. 12 ........................... 398, 490-91, 497

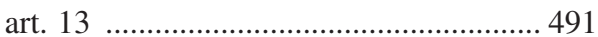

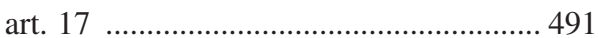

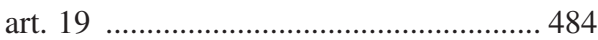

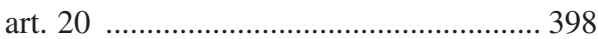

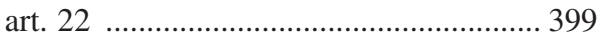

art. 23 ....................................................... 399

art. 24 ......................................... 331, 399

art. 32 ...................................... 398, 484

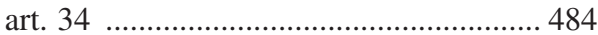

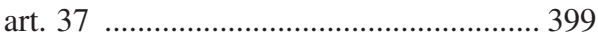

art. 38 ....................................... 397, 484

art. 39 ................................... 399, 484, 496

Optional Protocol on the Involvement of Children in Armed Conflict 2000 397, 485

Optional Protocol on the Sale of Children,

Child Prostitution and Child

Pornography 2000 397,485

Convention on the Transboundary Effects of Industrial Accidents 1992

(UNECE) ................ 160-61, 165, 436-7

art. 2 ..................................................... 161

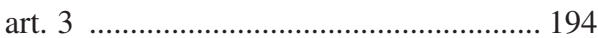

Annex I ............................................ 161, 194

Convention on Wetlands of International

Importance 1971 (Ramsar

Convention) 159

Convention relating to the Status of Refugees 1951 311-12, 373, 390

art. 4 390

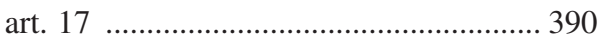

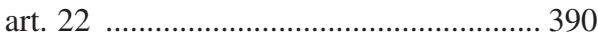

art. 33 ..................................................... 373

Convention Respecting the Laws and Customs of War on Land and its annex:

Regulations concerning the Laws and Customs of War on Land 1907 ......... 135 


\section{$\mathrm{xxx}$ Research handbook on disasters and international law}

Convention to Combat Desertification in those Countries Experiencing Serious Drought and/or Desertification 1994 ... 158-9, 182 art. 2 158

art. 3 $256-7$

Declaration on the Elimination of All Forms of Discrimination against Women 1967 395,397

Declaration on the Elimination of Violence against Women 1993 395

Declaration on the Protection of Women and Children in Emergency and Armed Conflict 1974 395

European Convention for the Protection of Human Rights and Fundamental Freedoms 1950

art. 2
art. 3 art. 4 .
Assistance 2000 .... 194, 353-4, 444, 451

Framework Convention on Climate Change 1992 (UNFCCC) ...... 157-8, 182, 256-7,

art. 3 256,310 art. 4 309,340

Preamble 310

General Agreement on Trade and Tariffs

(GATT) 1947 .................................... 31-2

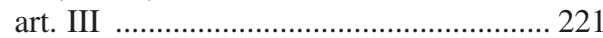

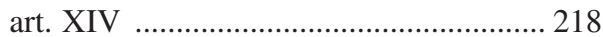

art. XIVbis .................................... 218, 220

art. XX ….......................... 211-12, 218-20

art. XXI ............................................... 220

Geneva Convention on the Amelioration of the Condition of the Wounded on the Field of Battle (Red Cross Convention) 1864 48

Geneva Convention Relative to the Treatment of Prisoners of War 1929

art. 78 133
Geneva Conventions 1949

First Convention for the Amelioration of the Condition of the Wounded and Sick in Armed Forces in the Field 1949

art. 3 .. 134, 139, 141, 144, 388, 461, 469

art. 9 ................................................. 134

art. 12 ............................................... 389

art. 13 .................................................. 133

Second Convention for the Amelioration of the Condition of the Wounded, Sick and Shipwrecked Armed Forces at Sea 1949

art. 3 .. 134, 139, 141, 144, 388, 461, 469

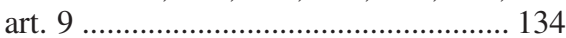

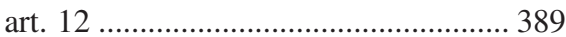

art. 13 ................................................ 133

Third Convention Relative to the Treatment of Prisoners of War 1949 ............... 304

art. 3 .. 134, 139, 141, 144, 388, 461, 469

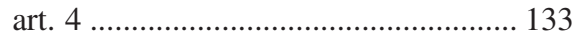

art. 9 ................................................. 134

art. 17 .................................... 388, 389

art. 20 .................................................. 305

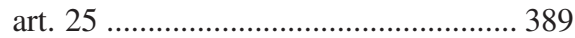

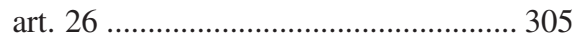

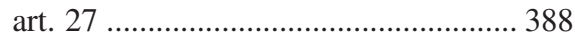

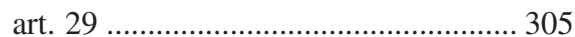

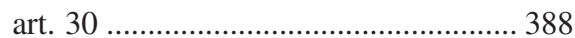

art. 46 .............................................. 305

Fourth Convention on the Protection of Civilian Persons in Time of War 1949 ........................................ 9, 304 art. 3 .......... 134, 139, 141, 144, 461, 469

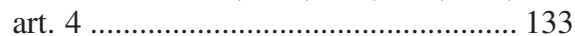

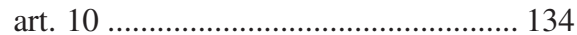

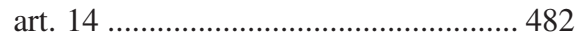

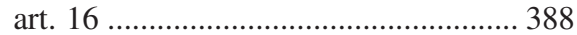

art. 17 ................................................ 482

art. 23 …....................................... 137-9

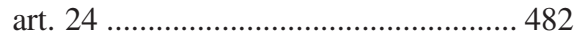

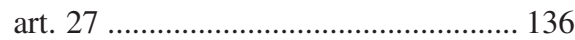

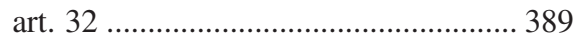

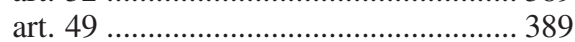

art. 50 .................................................. 482

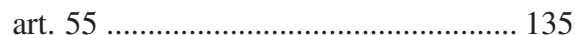

art. 59 ..................................... 135, 147

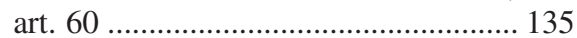

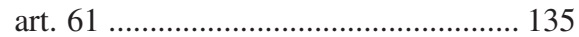

art. 62 ................................................. 134

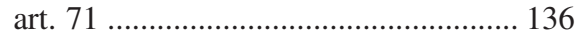

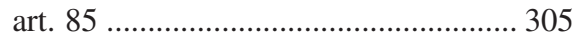

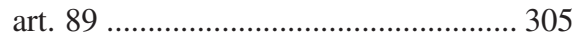

art. 127 ................................................ 305 
art. 146

503

art. 149

503

Additional Protocol I Relating to the Protection of Victims of International Armed Conflicts 1977 9, 304, 388, 461

art. 35 305

art. 52 305

art. 54 139,305

art. 55 305

art. 56 305

art. 61 353

art. 69 135-6

art. 70

art. 71 $137-9,141,145,147$

art. 72

137

art. 74

139

art. 75

482

art. 77

389

art. 90

482

art. 91

503

503

Additional Protocol II Relating to Victims of Non International Armed Conflicts 1977 9, 304, 388, 461 art. 1 $140-41$

art. 4 482

art. 5 305

art. 6 482

art. 14 305

art. 17 389

art. 18 134, 141, 144-5, 147, 469

Great Lakes Protocol on the Protection and

Assistance to Internally Displaced

Persons 2006 363,367

Hyogo Framework for Action 2005-2015 ........ 13, 64, 74-5, 171, 175, $194-5,225,242,328,445-6$

Inter-American Convention to Facilitate

Disaster Assistance 1991 232,441 $468-9$

International Conference on Small Island

Developing States 2014 $320-21$

International Convention for the Prevention of Pollution from Ships 1973 162

International Convention for the Safety of Life at Sea 1974 (SOLAS) 163

International Convention for the Settlement of Investment Disputes 1966

(ICSID) 208,212

International Convention for the Suppression of Acts of Nuclear Terrorism 2005 ... 126 International Convention on Civil Liability for Oil Pollution Damage 1969 $163-4$
International Convention on Oil Pollution Preparedness, Response and Cooperation 1990 163,437

International Convention on the Establishment of an International Fund for Compensation for Oil Pollution Damage 1971 $163-4$

International Convention on the Protection of the Rights of All Migrant Workers and Members of Their Families 1990 ..... 364, 379

International Covenant on Civil and Political Rights 1966

art. 2
art. 4
art. 6
art. 7

International Covenant on Economic, Social and Cultural Rights 1966 ... 24, 106, 261, $313,362,473,512$ art. 2 $314,330,339,369,394,473$

art. 3 314 art. 4 95,314

art. 9 339

art. 10 339,396

art. 11 313,339

art. 12 313,473

art. 21 256

art. 23 256

Optional Protocol 2008 ........................... 512

International Energy Charter ...................... 210 art. 10 213-14

art. 12 216

International Treaty on Plant Genetic

Resources for Food and Agriculture 2001 268

Istanbul Convention on Temporary Admission 1990 234

Joint Convention on the Safety of Spent Fuel Management and the Safety of Radioactive Waste Management 1997 167 


\section{xxxii Research handbook on disasters and international law}

Kuwait Regional Convention for Cooperation on the Protection of the Marine Environment from Pollution 1978 .... 437

Kyoto Convention on the Simplification and Harmonisation of Customs Procedures 1973 $233-4$

Kyoto Protocol to the United Nations

Framework Convention on Climate Change 1997 182 art. 3 182 art. 10 310

Marrakech Agreement Establishing the World

Trade Organization 1994

Measures to Expedite International Relief 1977 53,55

Memorandum of Agreement between the South Australian Metropolitan Fire Service and the Tonga Fire Service for a Long-term Partnership in Matters Relating to Fire and other Emergencies (Draft, 2010) 349

Memorandum of Understanding between Ghana and British Columbia 1999 .... 346

Nairobi Convention for the Protection, Management and Development of the Marine and Coastal Environment of the Eastern African Region 1985 438

Nansen Initiative Protection Agenda 2012 $16,374,376$

New York Convention on the Recognition and Enforcement of Foreign Arbitral Awards 1958 513

North American Free Trade Agreement 1992 (NAFTA) 209-10 art. 1102 221-2

Paris Agreement on Climate Change 2015 $2,310-11,317$

Protocol against the Smuggling of Migrants by Land, Sea and Air 2000 396

Protocol Concerning Cooperation and Development in Combating Oil Spills in the Wider Caribbean Region 1983

(Wider Caribbean Protocol) 438

Protocol Concerning Cooperation in Combating Marine Pollution in Cases of Emergency in the Eastern African Region 1985 (East African Protocol) 438

Protocol on Biosafety to the Convention on Biological Diversity 2000 (Cartagena Protocol) 158,182
Protocol on Cooperation in Combating Pollution of the Black Sea Marine Environment by Oil and Other Harmful Substances in Emergency Situations 1992 438

Protocol on Persistent Organic Pollutants 1988

Protocol on Preparedness, Response and Cooperation to Pollution Incidents by Hazardous and Noxious Substances 2000 (OPRC-HNS Protocol)

Protocol to Prevent, Suppress and Punish Trafficking in Persons, Especially

Women and Children 2000 396

Rio Declaration on Environment and

Development 1992 ... 157, 159, 161, 182,

$184-5,325,344$

art. 2 188

art. 3 184

art. 8 185

Principle 1 ........................................... 185

Principle 3 ......................................... 185

Principle 5 ................................ 185, 196

Principle 6 .......................................... 186

Principle 7 ................................. 186, 310

Principle 8 ...................................... 185-6

Principle 9 ...................................... 186

Principle 14 ........................................ 186

Principle 15 ....................................... 190

Principle 18 ................................ 185, 190

Rome Declaration on World Food Security

1996 254

Rome Statute of the International Criminal Court 1998 $111,113,306$ art. 6 306-7 art. 7 ......................................... 117, 483 art. $8 \ldots \ldots \ldots \ldots \ldots \ldots . .118,136,306,389,483$ art. 30 122

art. 31 127

Sendai Framework for Disaster Risk

Reduction 2015-2030 ............. 1, 14-15, $17,60,94,119,123-4,171,175,194-5$, $246,270,303,319,328-9,363,365-6$, 430-31, 510

Preamble 196

Social Security (Minimum Standards) Convention 1952 24

Southern African Development Community Model Bilateral Investment Treaty (July 2012) 211,214 
Tampere Convention on the Provision of

Telecommunication on the Provision of

Telecommunication Resources for

Disaster Mitigation and Relief

Operations 1998 ......... 4-6, 57, 194, 231, $233,246,444,458,469$

art. 1 ... 233

art. 4 468,476

art. 5 232

Treaty of Lisbon Amending the Treaty on European Union and the Treaty Establishing the European Community 2007 286

Treaty of Peace and Friendship between India and Nepal 1950 364

Treaty of the Functioning of the European Union 2012

art. 4 286

art. 114 286

art. 192 286

art. 194 286

art. 352

Treaty on the Non-Proliferation of Nuclear Weapons 1968 (NPT) 286

United States Model Bilateral Investment Treaty 211,214 art. 18 216 168
Universal Declaration on Human Rights

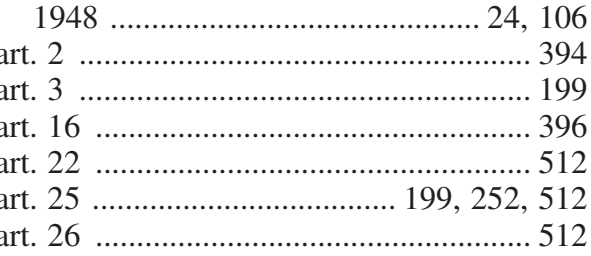

Vienna Convention on Civil Liability for Nuclear Damage 1963 167

Vienna Convention on the Law of Treaties 1969 $317-18$

art. 31

Wildfire Arrangement between the United States and Australian Participating Agencies 2002 346,348

Wildfire Arrangement between the United States and New Zealand Participating Agencies 2002 346,348

Wildfire Protection Agreement between United States and Mexico 1999 .... 345-7

World Conference on Disaster Reduction 2005 (Kobe)

World Conference on Disaster Risk Reduction 2015 (Sendai) 181

World Conference on Natural Disaster Reduction 1994 (Yokohama) .74 


\section{TABLE OF PRIMARY LEGISLATION/STATUTES}

\section{Bhutan}

Disaster Management Act 2013 235

\section{Canada}

Emergency Management Act 2007 431

\section{European Union}

Directive 96/82/EC on the Control of Major-Accident Hazards Involving Dangerous Substances

Directive 96/92/EC Concerning Common

Rules for the Internal Market in Electricity (First Electricity

Directive)

Directive 98/30/EC Concerning Common

Rules for the Internal Market in Natural

Gas (First Gas Directive) 285

Directive 2000/60/EC Establishing a

Framework for Community Action in the

Field of Water Policy 165

Directive 2003/54/EC Concerning Common

Rules for the Internal Market in

Electricity (Second Electricity

Directive) 286

Directive 2003/55/EC Concerning Common Rules for the Internal Market in Natural Gas (Second Gas Directive) 286

Directive 2003/105/EC on the Control of Major Accident Hazards Involving Dangerous Substances 161

Directive 2004/83/EC on Minimum Standards for the Qualification and Status of Third Country Nationals or Stateless Persons as Refugees $311-12$

Directive 2005/89/EC Concerning Measures to Safeguard Security of Electricity Supply and Infrastructure Investment (Electricity Supply Directive) ... 288, 289

Directive 2008/114/EC on the Identification and Designation of European Critical Infrastructures and the Assessment of the Need to Improve their Protection (ECI Directive) 288
Directive 2009/72/EC Concerning Common Rules for the Internal Market in Electricity (Third Electricity Directive) 286-7

Directive 2009/73/EC Concerning Common Rules for the Internal Market in Natural Gas (Third Gas Directive) 285,287

Directive 2009/119/EC Imposing an Obligation on Member States to Maintain Minimum Stocks of Crude Oil and/or Petroleum Products (Oil Stockholding Directive) 289

Directive 2013/30/EU on the Safety of Offshore Oil and Gas Operations .. 438-9

\section{India}

Bhopal Gas Leak Disaster (Processing of Claims) Act 1985 517

Disaster Management Act 2005 292

Petroleum and Natural Gas Regulatory Board Act 2006 292

\section{Indonesia}

Law Concerning Disaster Management, No. 24 of 2007 432

Law of the Republic of Indonesia concerning

Disaster Management 2007 234-5

\section{International}

Rome Statute of the International Criminal Court 1998 $111,113,306$

art. 6 $306-7$

art. 7 117,483

art. 8 389,483 art. 30 122 art. 31 127

Statute of the International Court of Justice 1945

art. 1 504

art. 36 504

\section{Liberia}

Children's Act 2012 498

\section{South Africa}

Disaster Management Act 2002 $432-4$ 
Disaster Management Amendment Act

2015 433

\section{Turkey}

Catastrophe Insurance Law, Law No. 6305 of 2012

\section{United Kingdom}

Civil Contingencies Act 2004 432,434

Energy Act 1976

\section{United States}

Clean Air Act 1970 ..................................... 282

Energy Policy Act 2005 .............................. 282

Energy Policy and Conservation Act 1975 $281-2$

Homeland Security Act 2002 …............... 281

International Emergency Economic Powers Act 1977 282 Natural Gas Policy Act 1978 .................... 282

Robert T Stafford Disaster Relief and Emergency Assistance Act 431 


\section{TABLE OF SECONDARY LEGISLATION}

\section{European Union}

Decision No 1313/2013/EU on a Union Civil

Protection Mechanism $442-3$

Regulation (EC) No 713/2009 Establishing an Agency for the Cooperation of Energy

Regulators
Regulation (EC) No 714/2009 on Conditions for Access to the Network for Cross-Border Exchanges in Electricity 286

Regulation (EC) No 715/2009 on Conditions for Access to the Natural Gas Transmission Networks 286

Regulation (EU) No 994/2010 Concerning Measures to Safeguard Security of Gas Supply (Gas Supply Regulation)

Recital 4 287

Recital 13 288 


\section{TABLE OF OFFICIAL DOCUMENTS}

\section{American Petroleum Institute}

Security Vulnerability Assessment Methodology for the Petroleum and Petrochemical Industries (May 2003) $283-4$

\section{British Red Cross}

Analysis of Law in the United Kingdom pertaining to Cross-Border Disaster Relief (2010)

\section{Committee on World Food Security}

Report by the High Level Panel of Experts on Food Security and Nutrition on Biofuels and Food Security (2013) 259

\section{Economic Commission for Europe}

Draft Guidance Document on Best Available Techniques to Control Emissions of Persistent Organic Pollutants from Major Stationary Sources (October 2009) ... 343

\section{European Union}

General Conditions Applicable to Humanitarian Aid Actions Financed by the European Union (January 2014) 236

Humanitarian Aid and Civil Protection, Children in Conflict - ECHO Factsheet (2014) 479

Implementing the partnership for growth and jobs: making Europe a pole of excellence on corporate social responsibility COM(2006) 136 final (March 2006) 238

In-depth study of European Energy Security. Accompanying the document. Communication from the Commission to the Council and the European Parliament: European energy security strategy (2014) 330 final/3 (2014) .... 276

Towards a stronger European disaster response: the role of civil protection and humanitarian assistance, $\operatorname{COM}(2010)$

600 final (October 2010) 236

Water, Sanitation and Hygiene: Meeting the

Challenge of Rapidly Increasing

Humanitarian Needs in WASH (DG

Humanitarian Aid and Civil Protection,

May 2014)

\section{Food and Agriculture Organization}

Benefit-Sharing Fund Project: Guatemala Fact

Sheet 268

Fire Management Working Paper 17: Fire Management: Voluntary Guidelines (2006)

Fire Management Working Paper 18: Fire Management: Review of International Cooperation 2006 341,352

Food and Agriculture Based Approaches to Safeguarding Nutrition Before, During and After Emergencies: The Experience of FAO (2011) 252

Forestry Paper 151 Fire Management Global Assessment 2006 341

Impact of Disasters and Emergencies on Animal Genetic Resources (November 2006) 268

Resilient Livelihoods: Disaster Risk Reduction for Food and Nutrition Security Framework Programme (2013)

Role in Disaster Risk Reduction 252

Strategy to Enhance International Cooperation on Fire Management (June 2008) .... 336,

State of Food Insecurity in the World 2012: Economic Growth is Necessary but not Sufficient to Accelerate Reduction of Hunger and Malnutrition (2012) ....... 257

State of Food Insecurity in the World 2014: Strengthening the Enabling Environment for Food Security and Nutrition (2014) 251

Voluntary Guidelines on the Responsible Governance of Tenure of Land, Fisheries and Forests in the Context of National Food Security (2012) 258

Voluntary Guidelines to Support the Progressive Realization of the Right to Adequate Food in the Context of National Food Security (November 2004) 
xxxviii Research handbook on disasters and international law

\section{Global Humanitarian Forum}

Human Impact Report: Climate Change. The

Anatomy of a Silent Crisis (2009) .... 302

\section{Institut de Droit International}

Resolution Concerning the Protection of Human Rights and the Principle of Non-intervention in Internal Affairs of States (1989) 469-70

\section{Inter-Agency Standing Committee}

Framework on Durable Solutions for

Internally Displaced Persons (2010) . 371

Humanitarian System-Wide Emergency

Activation: Definition and Procedures

(April 2012) 300

Operational Guidelines for Protection of

Persons in Situations of Natural

Disasters (2011) ....... 11, 95-8, 107, 314, 370

\section{Intergovernmental Panel on Climate Change}

Climate Change 2014: Synthesis Report (2015) 299

Managing the Risks of Extreme Events and Disasters to Advance Climate Change Adaptation (2013) 170

\section{Internal Displacement Monitoring Centre}

Global Estimates 2015: People Displaced by Disasters (2015)

\section{International Commission of Jurists}

Maastricht Principles on Extraterritorial Obligations of States in the area of Economic, Social and Cultural Rights 2012

\section{International Commission on Intervention and State Sovereignty}

The Responsibility to Protect: Report of the International Commission on
Intervention and State Sovereignty

(December 2001) 69-70, 73, 78, 84

105,466

\section{International Criminal Court}

Elements of Crimes 122

\section{International Energy Agency}

Energy Policies of IEA Countries: European Union (2014) 276

Energy Policies of IEA Countries: The United States (2014) 277,282

Energy Security and Climate Policy Assessing Interactions (2007) 293

Energy Supply Security: Emergency Response of IEA Countries 2014 273

\section{International Federation of Red Cross and Red Crescent Societies}

About the Disaster Law Programme (August 2014) 79,403

Action Plan for Implementing International Humanitarian Law (Annex to Resolution

2) (2011) $139-40$

Annotation to the Draft Guidelines for the Domestic Facilitation and Regulation of Natural Disaster Relief and Initial Recovery Assistance (October 2007) 79,233

Code of Conduct for International Red Cross/ Red Crescent and Non-governmental Organizations in Disaster Relief 1994 56, 239, 251, 263, 474

Commentary on the Additional Protocols of 8 June 1977 to the Geneva Conventions of 12 August 1949 (1987) ... 136-7, 139-41

Contingency planning guide (2012) 429

Disaster Law Programme Mid-Year Report 2015

Disaster Relief and International Law Protections of Human Beings in Natural Disaster Situations 1981 $55-6$

Effective Law and Regulation for Disaster Risk Reduction: A Multi-Country Report (IFRC/ UNDP, 2014) 64, 96, 404

Ethical Principles Guiding the ICRC's Partnerships with the Private Sector (February 2002) 244 
Fundamental Principles of the Red Cross and

Red Crescent (1996) 252

Geneva Convention IV Relative to the

Protection of Civilian Persons in Time of

War: Commentary (1958) 135,387

Global partnership announced between

Ericsson and Red Cross Red Crescent

(September 2002) 243

Guidelines for the Domestic Facilitation and

Regulation of International Disaster

Relief and Initial Recovery Assistance

(2007) (IDRL Guidelines) ..... 60, 79, 84,

$115,232-3,263,266-7,338,457$

How is the Term 'Armed Conflict' Defined in

International Humanitarian Law?

(Opinion Paper, 2008) 140

International Disaster Response Law (IDRL)

in Botswana (2013) 235

International Disaster Response Law (IDRL)

Project Report 2002-2003 .. 57

International Humanitarian Law and the

Challenges of Contemporary Armed

Conflicts (2011) $142,149,151$

Introduction to the Guidelines $2011 \ldots . .60,80$,

Law and Legal Issues in International Disaster Response: A Desk Study (2007) ...... 132, $230,481-2$

Legal Issues from the International Response to the Tsunami in Indonesia (July 2006) 229,238

Legal Preparedness for Responding to

Disaster and Communicable Disease

Emergency in Lao PDR (2009) 235

Memorandum of Understanding between IFRC and UN Office for Coordination of Humanitarian Affairs (November 2011) 61

Model Act for the Facilitation and Regulation of International Disaster Relief and Initial Recovery Assistance (2013) .... 63, 80, 229-30, 232, 234

Principles and Rules of Red Cross Disaster Relief 1969 55

Q\&A and Lexicon on Humanitarian Access (2014) $143-4$

Ready or Not? Third progress report on the implementation of the Guidelines for the domestic facilitation and regulation of international disaster relief and initial recovery assistance (Nov 2015) ......... 47, $61-3,65$

Report on the Survey on Disaster Relief,

Regulation and Protection (November

2015)

Resolution 7 - Strengthening Disaster Law

(December 2011)

Review of Strategy 2010 56

Strengthening Legal Protection for Persons

Deprived of their Liberty in Relation to

Non-International Armed Conflict;

Regional Consultations 2012-13 ...... 148

Strengthening the Legal Framework for

International Response to Disasters,

Background Document 2007 56

Syria: Water Used as Weapon of War (2

September 2015) 300

UN General Assembly Resolutions mentioning the IDRL Guidelines ........ 60

World Disasters Report 2000 ....... 46, 52, 386

World Disasters Report 2001 ....................... 46

World Disasters Report 2015 ................ 47, 64

\section{International Food Safety Authorities \\ Network}

Food Safety in Natural Disasters (September 2005) 260

\section{International Fund for Agricultural Development}

Framework for Bridging Post-Crisis Recovery and Long-term Development (September 1998) 265

Guidelines for Disaster Early Recovery (2011) 265

Policy on Crisis Prevention and Recovery (April 2006) 265

Promoting the Resilience of Poor Rural Households (2015) 259

\section{International Institute for Sustainable Development}

The Full Protection and Security Standard Comes of Age: Yet Another Challenge for States in Investment Treaty Arbitration (November 2011) 
International Institute of Humanitarian Law

Guiding Principles on the Right to Humanitarian Assistance (1993) (San Remo Principles) 138, 458-9, 469

\section{International Law Association}

Berlin Rules on Water Resources (August 2004) (Berlin Rules) .............. 307-8, 316

Water Resources Committee Report, Berlin Conference 2004: Dissenting Opinion (August 2004) 308

\section{International Law Commission}

Draft Articles on Prevention of Transboundary Harm from Hazardous Activities

(2001) 189,344

art. 3 $188-90$

art. 4 352

art. 16 160

art. 17 160

Draft Articles on Responsibility of States for Internationally Wrongful Acts

(December 2001) $70,86-8,465$, $473-4$

Annex 351

art. 2 351

art. 4 352

art. 40 87

art. 41 87

art. 48 507

Draft Articles on the Effects of Armed

Conflicts on Treaties 2011 .......... 215-16 art. 3 $215-16$ art. 5 216

Draft Articles on the Law of Transboundary

Aquifers (2008) $307,309,319,418$, $449,458,507$

Draft Articles on the Protection of Persons in the Event of Disasters (May 2014) ...... 65-7, 69-70, 76-7, 80-81, 84, $98-100,150,152,256,338,363,383$, 406, 414, 449-50, 502, 507-8

art. 1 $466-7$

art. 2 $154-5,363-4,464,470,472$

art. 3 $100,111,132,154-5,457$

art. 4 ... 457 art. 5 99,262

art. 6 $99,262,464,470$

art. 7 99

art. $8 \ldots 99,150,233,262,455-6,464,470$ art. 9 150

art. 10 $150,364,459$

art. $11 . .99,150,256,364,450,459,463-4$ art. 12 .80-81, 99, 151, 262, 403, 430, 450, 456, 463-4, 475-6

art. $13.81,262,364,450,459,461,463-4$, 476

art. $14 \ldots . . .81,150,262,369,456,461,475$ art. 15 .................................... 459,476 art. 16 ...... 150, 453, 457, 460-65, 467-70, 472,477

art. 17 $150,262,459$

art. 18 262

art. 19 $151,459,470$

art. 20 150

art. 21 150,481

Draft Principles on the Allocation of Loss in the Case of Transboundary Harm Arising out of Hazardous Activities (2006) ... 160

Protection of Persons in the Event of Disasters: Memorandum by the Secretariat (2007) ......... 47, 66, 178, 197, 233, 458

Provisional Summary Record of the 2978th ILC Meeting ........................................... 66

Provisional Summary Record of the 3175th ILC Meeting 186,189

Provisional Summary Record of the 3178th ILC Meeting 199

Report on the work of the sixty-second session of the UN (2010) .. 197, 462, 474

Report on the work of the sixty-fourth session of the UN (2012) 455,472

Report on the work of the sixty-fifth session of the UN (2013) ...... 193, 458, 459, 467

Report on the work of the sixty-sixth session of the UN (2014) ..... 133, 150, 155, 193, 215, 262, 369, 470, 475-6, 506

Summaries of the Work of the ILC: Protection of persons in the event of disasters $65-6,76-7$

\section{International Monetary Fund}

Fiscal Policy and Income Inequality (IMF Policy Paper, 2013) 43 
Spillovers in International Corporate Taxation (IMF Policy Paper, 2014) 34

\section{International Strategy for Disaster Reduction}

Relationship between natural disasters and poverty: A Fiji case study (2009)

\section{International Work Group for Indigenous Affairs}

REDD+ and Indigenous Peoples: A Briefing

Paper for Policymakers (2012) 260

\section{NATO Cooperative Cyber Defence Center of Excellence}

Tallinn Manual on the International Law Applicable to Cyber Warfare 409 , 419-20, 424, 426

\section{Organisation for Economic Co-Operation and Development}

Guidelines for Multinational Enterprises (2011) 240

Risk Awareness Tool for Multinational Enterprises in Weak Governance Zones (June 2006)

\section{Task Force on Ethical and Legal Issues in Humanitarian Assistance}

Mohonk Criteria for Humanitarian Assistance in Complex Emergencies (February 1994) 458-60, 462-3, 468

\section{UN Association of United States}

Acts of Nature, Acts of Man: The Global Response to Natural Disasters 1977 ... 55

\section{United Kingdom Government}

Addressing Lessons from the Emergency Response to the 7 July 2005 London Bombings: What we learned and what we are doing about it (September 2006)

\section{United Nations}

Activities of the International Decade for Natural Disaster Reduction (July 1999) 74

Agenda 21 (1992) $157,182,185,325$

Cape Town Principles on Prevention of

Recruitment of Children into the Armed

Forces and Demobilization of Child

Soldiers in Africa 1997 (UNICEF) ... 485 Charter 1945

art. 1 130,195

art. 2 $137,351,411-15,420-25,501$

art. 56 473 art. 96 508

Children and Truth Commissions (UNICEF, August 2010) 493

Concluding Observations of the Human Rights Committee, Democratic People's

Republic of Korea (August 2001) ..... 365

Conclusion on Refugees with Disabilities and Other Persons with Disabilities Protected and Assisted by UNHCR (October 2010) 391

Conclusions Adopted by the Executive Committee on the International Protection of Refugees (UNHCR, 2009)

Declaration on Environment and Development (1992, Rio Declaration) ... 157, 159, 161, $182,184-5,325,344$

art. 2 188

art. 3 184

art. 8 185

Principle 1 185

Principle 3

Principle 5 185

Principle 6 185,196

Principle 7 186

Principle 8 186,310

Principle 9 $185-6$

Principle 14 186

Principle 15 186

Principle 18 190 185,190

Declaration on the Human Environment (1972, Stockholm Declaration) .... 156-7, $159,182,324$

Principle 21 188

Development of Guidelines on the Role and Social Responsibilities of the Private Sector (UN Secretary-General, February 2000) 238 
Disaster through a Different Lens: Behind Every Effect, There Is a Cause

(UNISDR, 2011) 126

Draft Articles on the Protection of Persons in the Event of Disasters (July 2009) 6-11, 17-18

Draft Convention on Expediting the Delivery of Emergency Relief 1984 54-5, $474-5$

Early Warning, Assessment and the Responsibility to Protect (July 2010) .75

Effective Law and Regulation for Disaster Risk Reduction: A Multi-Country Report (IFRC/ UNDP, 2014) $64,96,404$

Environment and Disaster Risk: Emerging Perspectives (2007) (UNEP) 185

Factsheet on Water Quality (2013) 322

Final Research-based Report of the Human Rights Council Advisory Committee on Best Practices and Main Challenges in the Promotion and Protection of Human Rights in Post-Disaster and Post-Conflict Situations (February 2015) ........ 237, 457

Follow-up to the Second World Assembly on Ageing (July 2011) 402

General Comment No 1: Article 12: Equal Recognition before the Law (CPRD, May 2014) 400

General Comment No 2: International Technical Assistance Measures (Art 22 of the ICESCR) (CESCR, February 1990) 473

General Comment No. 3: The Nature of State Parties' Obligations (Art 2, para 1 of the ICESCR) (CESCR, December 1990) .......... 81, 314, 368, 395, 473, 484

General Comment No. 4: The Right to Adequate Housing (Art 11(1) of the ICESCR) (CESCR, December 1991) 81,395

General Comment No. 6: Article 6 (Right to Life) (ICCPR, April 1982) ........ 199, 333

General Comment No. 7: Regarding the Right to Adequate Housing (Art 11(1) of ICESCR) (forced evictions) (CESCR, May 1997) 473

General Comment No. 8: Economic Sanctions and Economic, Social and Cultural Rights (CESCR, December 1997) .... 199

General Comment No. 12: The Right of the Child to be Heard (CRC, July 2009) 398
General Comment No. 12: The Right to Adequate Food (Art 11 of the ICESCR) (CESCR, 12 May 1999) ..... 81, 252, 261, $395,468,471$

General Comment No. 13: The Right of the Child to Freedom from all Forms of Violence (CRC, April 2011) ... 398

General Comment No. 14: Regarding the Right to the Highest Attainable Standard of Health (Art 11 of ICESCR) (CESCR, August 2000) 468

General Comment No. 14: The Rights of the Child to Have His or Her Best Interests Taken as a Primary Consideration (Art 3(1)) (CRC, May 2013) .... 398, 468, 491

General Comment No. 15: The Right of the Child to the Enjoyment of the Highest Attainable Standard of Health (Art 24) (CRC, April 2013) 484

General Comment No. 15: The Right to Water (arts 11 and 12 of the ICESCR)

(CESCR, January 2003) .... 313, 330, 473

General Comment No. 31: The Nature of the General Legal Obligation Imposed on States Parties to the ICCPR (CCPR, May 2004) 199,333

General Comment No. 36: Article 6: Right to Life (CCPR, September 2015) .......... 200

Global Assessment Report on Disaster Risk Reduction (UNISDR, 2013) 299

Global Assessment Report on Disaster Risk Reduction (UNISDR, 2015) ...... 299, 301

Global Compact ........................................ 240

Global Trends 2013: War's Human Cost (UNCHR, 2014) 384

Global Trends 2014: World at War (UNHCR, 2015) 358

Guidelines on Cooperation between the UN and the Business Sector (November 2009) 244

Guidelines on Justice in Matters Involving Child Victims and Witnesses of Crime (ECOSOC) (July 2005) 496

Guiding Principles for Public-Private Collaboration for Humanitarian Action (OCHA, 2007) 225-6, 244

Guiding Principles on Business and Human Rights UNCHR (June 2011) ....... 240-41

Guiding Principles on Internal Displacement (February 1998) $138,311,363$, 368-71, 379-80, 485

Handbook on Procedures and Criteria for Determining Refugee Status under the 
1951 Convention and the 1967 Protocol relating to the Status of Refugees

(UNHCR, 1992) 378

How WASH relates to Health, Education and

Development (UNESCO, January 2016)

Human Development Report 2006: Beyond

Scarcity: Power, Poverty and the Global

Water Crisis (UNDP, 2006) 300

Human Development Report 2011:

Sustainability and Equity: A Better

Future for All (UNDP, 2011) 299

Human Development Report 2014 -

Sustaining Human Progress: Reducing

Vulnerabilities and Building Resistance

(2014)

Human Rights and Access to Safe Drinking

Water and Sanitation (UNHR, October

2010) 313

Human Rights in Palestine and other

Occupied Arab Territories: Report of the United Nations Fact-Finding Mission on the Gaza Conflict (September 2009)

Human Rights, Poverty Reduction and

Sustainable Development: Health, Food and Water: A Background Paper

(OHCHR, 2002) 321,327

Humanitarian Response Review: An

Independent Report Commissioned by the United Nations Emergency Relief

Coordinator and

Under-Secretary-General for

Humanitarian Affairs (OCHA) (August

2005) 241

Hyogo Framework for Action

2005-2015 ........ 13, 64, 74-5, 171, 175, $181,185,194-8,196,225,242,328$,

Impact of Armed Conflict on Children 445-6

(August 1996) 490

Impacts of Disasters since the 1992 Rio de

Janeiro Earth Summit (2012)

(UNISDR) 177

Implementation of the International Strategy

for Disaster Reduction (August

2013) 180

Implementation of the World Programme of

Action for Youth: Progress and

Constraints with Respect to the

Well-Being of Youth and Their Role in

Civil Society (October 2008) 493
Implementing the Responsibility to Protect

(January 2009) 72-3, 118

In Larger Freedom: Towards Development, Security and Human Rights for All

(March 2005) .... 75-6, 78, 320, 403, 488

International Code of Conduct for Information Security 2011 (draft proposal from

Russia, China, Tajikistan and

Uzbekistan) 409

International Cooperation on Humanitarian Assistance in the Field of Natural Disasters, from Relief to Development (August 2005) 225

International Cooperation on Humanitarian Assistance in the Field of Natural Disasters, from Relief to Development (December 2008) 79

International Criminal Justice and Children (UNICEF, September 2002) ...... 480, 492

International Strategy for Disaster Reduction (1999)

Machel Study 10 Year Strategic Review: Children and Conflict in a Changing World (2009)

Memorandum of Understanding between IFRC and UN Office for Coordination of Humanitarian Affairs (November 2011) 61

Millennium Development Goals and Beyond 2015: Goal 7: Ensure Environmental Stability $325-6$

Model Rules for Disaster Relief Operations (1982) .54

A More Secure World: Our Shared Responsibility (2004) 487

Natural Disasters and Vulnerability Analysis: Report of Expert Group Meeting (July 1979) 180

New Delhi Statement: Global Consultation on Safe Water and Sanitation (October 1990) $324-5$

Non-legally Binding Authoritative Statement of Principles for a Global Consensus on the Management, Conservation and Sustainable Development of all Types of Forests (August 1992) 340

Options for IIA Reform: Treaty Examples and Data (UNCTAD, June 2015) 211

Paris Principles on Children Associated with Armed Forces (February 2007) ......... 485

Prevention of Armed Conflict (June 2001) 487,496 


\section{xliv Research handbook on disasters and international law}

Progress on Sanitation and Drinking Water: 2015 Update and MDG Assessment (UNICEF/ WHO, 2015) 299

Progress Report on the Research-based Report of the Human Rights Council Advisory Committee on Best Practices and Main Challenges in the Promotion and Protection of Human Rights in Post-Disaster and Post-Conflict Situations (August 2014) 362

Progressive Development of the Principles and Norms of International Law Relating to the New International Economic Order (1984) 186

Promotion and Protection of All Human Rights, Civil, Political, Economic, Social and Cultural Rights, Including the Right to Development: Human Rights and International Solidarity (August 2008)

Promotion and Protection of the Rights of Indigenous Peoples in Disaster Risk Reduction, Prevention and Preparedness Initiatives (April 2014) 202, 321

Protection of Internally Displaced Persons in Situations of Natural Disasters. A Working Visit to Asia by the Representative of the United Nations Secretary-General on the Human Rights of Internally Displaced Persons (OHCHR, 2005) 367

Recent Trends in IIAs and ISDS (UNCTAD, February 2015) 212

Reform of Investor-State Dispute Settlement: in Search of a Roadmap (IIA Issues Note no. 3, June 2013 213

Refugee Children: Guidelines on Protection and Care (UNHCR, 1994) 391

Report of the Commission of Experts of the Resident of the United Nations General Assembly on Reforms of the International Monetary and Financial System (Sept 2009) 23

Report of the Detailed Findings of the Commission of Inquiry on Human Rights in the Democratic People's Republic of Korea (February 2014)

Report of the Group of Governmental Experts on Developments in the Field of Information and Telecommunications in the Context of International Security

(June 2013) 419

Report of the Representative of the

Secretary-General on the Human Rights of Internally Displaced Persons (March 2009) 367

Report of the Secretary General's Panel of

Experts on Accountability in Sri Lanka (March 2011) 125

Report of the Special Committee on

Principles of International Law

Concerning Friendly Relations and Co-Operation among States (October 1969) 412

Report of the Special Rapporteur on the

Human Right to Safe Drinking Water and Sanitation: Stigma and the Realization of the Human Rights to

Water and Sanitation (July 2012) ...... 317

Report of the Special Rapporteur on the

Human Rights of Internally Displaced

Persons: Addendum, Mission to Haiti

(May 2015) 368

Road Map towards the Implementation of the

United Nations Millennium Declaration

(September 2001) 340

The Rule of Law and Transitional Justice in Conflict and Post-Conflict Societies

(August 2004) 487

Sendai Framework for Disaster Risk

Reduction 2015-2030 (March 2015) ... 1, 14-15, 17, 60, 94, 119, 123-4, 171, 175, 181, 194-8, 196, 246, 270, 303, 319, 328-9, 363, 365-6, 430-31, 510

Special Rapporteur's Preliminary Report on the Protection of Persons in the Event of Disasters (May 2008) .... 50, 196, 237 , 460,470

Special Rapporteur's Second Report on the Protection of Persons in the Event of Disasters (May 2009) ....... 4-6, 197, 233, 502

Special Rapporteur's Third Report on the Protection of Persons in the Event of Disasters (May 2010) 197,471

Special Rapporteur's Fourth Report on the Protection of Persons in the Event of Disasters (May 2011) ... 238, 453, 467-9, $473,475-6$

Special Rapporteur's Fifth Report on the Protection of Persons in the Event of Disasters (May 2012) $196-7,455$ 
Special Rapporteur's Sixth Report on the

Protection of Persons in the Event of Disasters (May 2013) ... 180, 186, 191-2, 196-8, 200, 436

Special Rapporteur's Seventh Report on the

Protection of Persons in the Event of

Disasters (February 2014) 112

State Responsibility and Prevention (July 2013) 75,77

Strategic Framework for Partnerships and Collaborative Relationships (UNICEF, 2009) 244

Strengthening Emergency Relief,

Rehabilitation, Reconstruction and Prevention in the Aftermath of the Indian Ocean Tsunami Disaster (December 2008) .79

Strengthening of the Coordination of

Emergency Humanitarian Assistance of the United Nations (March 2009) 79

Terminology on Disaster Risk Reduction (2009) (UNISDR) .... 180, 192, 300, 328, 404, 429

Six Grave Violations against Children in Armed Conflict: The Legal Foundation (Sec-Gen for Children in Armed Conflict, October 2009) 483

Transforming Our World: Human Rights in the 2030 Agenda for Sustainable Development (UNOCHR, 2015) ...... 321,

UNGA Resolution 35/18: Proclamation of the International Drinking Water Supply and Sanitation Decade (November 1980) 324

UNGA Resolution 35/56: Strengthening the Capacity of the United Nations System to Respond to Natural Disasters and other Disaster Situations (December 1980) 182

UNGA Resolution 36/225: Strengthening the capacity of the United Nations System to Respond to Natural Disasters and other Disaster Situations (December 1981) 469

UNGA Resolution 41/128: Declaration on the Right to Development (December 1986) 209,321

UNGA Resolution 42/169: International Decade for Natural Disaster Reduction (December 1987) 157,180
UNGA Resolution 43/131: Humanitarian assistance to victims of natural disasters and similar emergency situations (December 1988) 469

UNGA Resolution 44/263: International Decade on Natural Disaster Reduction (December 1989) 191

UNGA Resolution 46/108: Assistance to refugees, returnees and displaced persons in Africa (December 1991) 469

UNGA Resolution 46/119: Principles for the Protection of Persons with Mental Illness and the Improvement of Mental Health Care (December 1991) 399

UNGA Resolution 46/182: Strengthening of the Coordination of Humanitarian Emergency Assistance of the United Nations (December 1991) .... 50, 53, 177, 191-2, 198, 350, 369, 403, 436, 458, 486

UNGA Resolution 54/175: The Right to Development (February 2000) .. 321, 325

UNGA Resolution 54/233: Humanitarian Assistance in the Field of Natural Disasters from Relief to Development (February 2000) 486

UNGA Resolution 55/2: Millennium Declaration (September 2000) .......... 325,

UNGA Resolution 55/63: Combating the criminal misuse of information technologies (December 2000) 425

UNGA Resolution 56/103: International Cooperation on Humanitarian Assistance in the Field of Natural Disasters, From Relief to Development (February 2002)

UNGA Resolution 56/195: International Strategy for Disaster Reduction (January 2002) 242

UNGA Resolution 57/150: Strengthening the Effectiveness and Coordination of International Urban Search and Rescue Assistance (February 2003) 59-60, 350,354

UNGA Resolution 60/1: 2005 World Summit Outcome (October 2005) ..... 72, 89, 118, 467, 485

UNGA Resolution 62/98: Non-legally Binding Instrument on all Types of Forests (January 2008) 340

UNGA Resolution 62/141: Rights of the Child (February 2008) 485 
UNGA Resolution 63/137: Strengthening Emergency Relief, Rehabilitation, Reconstruction and Prevention in the Aftermath of the Indian Ocean Tsunami Disaster (December 2008) 79,403

UNGA Resolution 63/139: Strengthening the Coordination of Emergency

Humanitarian Assistance of the United Nations (March 2009) 79,460

UNGA Resolution 63/141: International Cooperation on Humanitarian Assistance in the Field of Natural Disasters, from Relief to Development (December 2008) $50,53,403$

UNGA Resolution 63/241: Rights of the Child (March 2009) 485

UNGA Resolution 64/292: The Human Right to Water and Sanitation (July 2010) 319

UNGA Resolution 66/99: Effects of armed conflict on treaties (2012) 316

UNGA Resolution 66/233: Towards Global Partnerships (March 2012 1989) ....... 191

UNGA Resolution 66/288: The Future We Want (2012) 170-71, 181

UNGA Resolution 68/102: Strengthening of the Coordination of Humanitarian Emergency Assistance of the United Nations (December 2013) 486

UNGA Resolution 68/157: The Human Right to Safe Drinking Water and Sanitation (December 2013) 303,330

UNGA Resolution 70/1: 2030 Agenda for Sustainable Development (October 2015) 303, 319, 403

UNGA Resolution 1386 (XIV): Declaration on the Rights of the Child (November 1959) 397

UNGA Resolution 1803 (XVII): Permanent Sovereignty over Natural Resources (December 1962) 209

UNGA Resolution 2034 (XX): Assistance in Cases of Natural Disaster (December 1965) .51

UNGA Resolution 2626 (XXV): International Development Strategy for the Second United Nations Development Decade (October 1970) 51

UNGA Resolution 2816 (XXVI): Assistance in Cases of Natural Disaster and other disaster situations (December 19671)
UNGA Resolution 2856 (XXVI): Declaration on the Rights of Mentally Retarded Persons (December 1971) .................. 400

UNGA Resolution 3171 (XXVIII): Permanent Sovereignty over Natural Resources (December 2015) 209

UNGA Resolution 3201 (S-VI): Declaration on the Establishment of a New International Economic Order (May 1974) 209

UNGA Resolution 3281(XXIX): 1974 Charter of Economic Rights and Duties of States (December 1974) 209

UNGA Resolution 3314 (XXIX): Definition of Aggression (December 1974) ....... 412

UNGA Resolution 3447 (XXX): Declaration on the Rights of Disabled Persons (December 1975) 400

UNGA Resolution S-19/2: Programme for the Further Implementation of Agenda 21 (September 1997) 183

UNGA Resolution S-27/2: A World Fit For Children (October 2002) 485

UNHCR Policy on Refugee Children (August 1996) 391

UNICEF's Role in Emergencies (May 2012)

UNSC Resolution 2165: Reports of the Secretary-General on the Sudan (2014)

Water Security \& the Global Water Agenda: A UN-Water Analytical Brief (UN-Water, October 2013) ..................... 298, 300-301

World Charter for Nature 1982 ................. 159

World Investment Report 2014 .................. 213

World Investment Report 2015 .......... 207, 213

World Summit Outcome 2005 (October 2005) ................... 72, 89, 118, 467, 485

World Water Development Report 3: Water in a Changing World (UNESCO, 2009) 295

World Water Development Report 4: Managing Water under Uncertainty and Risk (UNESCO, 2012) 295

World Water Development Report 2015: Water for a Sustainable World (UNESCO, 2015) $295,319,322$

Yokohama Strategy for a Safer World: Guidelines for Natural Disaster Prevention, Preparedness and Mitigation and Plan of Action (1994) (UNISDR) ............. 177-8, 180, 194, 328 
Tables of legislation xlvii

\section{United States Government}

Federal Response to Hurricane Katrina:

Lessons Learned (February 2006) . 434-5

Hurricane Katrina: A Nation Still Unprepared (2006) 434

International Strategy for Cyberspace:

Prosperity, Security, and Openness in a

Networked World (May 2011) 419

\section{US Energy Information Administration}

World Oil Transit Chokepoints Critical to

Global Energy Security (December

2014)

\section{US Federal Emergency Management Agency}

National Preparedness Cycle 429

\section{USAID}

Building Alliance Series: Emergency (June 2009)

\section{WaterAid}

Water Security Framework (2012) 298

\section{World Bank}

$4^{\circ}$ : Turn Down the Heat: Confronting the New Climate Normal (2014) 301

Guidelines on the Treatment of Foreign Direct Investment (1992) 209-10

Populations at Risk of Disaster: A Resettlement Guide (2011) 366

\section{World Commission on Environment and Development}

Our Common Future (Brundtland Report)

(1987) 179-82, 196

\section{World Food Programme}

Corporate Partnership Strategy

(2014-2017) 244

Food Security Monitoring System 256

Managing Weather Risk for Agricultural Development and Disaster Risk Reduction (January 2016) 266

Policy on Disaster Risk Reduction and Management: Building Food Security and Resilience (November 2011) 259

\section{World Health Organization}

Guidelines for Drinking-Water Quality

(2011) ................................................ 330

International Health Regulations (2008) ... 469

Preventing Diarrhoea through Better Water, Sanitation and Hygiene: Exposures and Impacts in Low- and Middle-Income Countries (2014) 322

United Nations Synthesis Report on Arsenic in Drinking Water 323

Use of improved sanitation facilities (2015) 322

Water-related Diseases: Lead poisoning (January 2016) .................................... 320

World Report on Disability (2011) ............ 384 
Susan C. Breau and Katja L.H. Samuel - 9781784717407 